\title{
Cochlear condition and olivocochlear system of gas station attendants exposed to organic solvents
}

\section{Condição coclear e do sistema olivococlear medial de frentistas de postos de gasolina expostos a solventes orgânicos}

\author{
Lenita da Silva Quevedo', Tania Maria Tochetto², Márcia do Amaral Siqueira³. \\ 1) College Degree. Speech Therapist, Master Student in Human Communication Disturb by Federal University of Santa Maria. \\ 2) $\mathrm{PhD}$. Associated Professor of Federal University of Santa Maria. \\ 3) Master in Human Communication Disturb by Federal University of Santa Maria. Speech therapist of Worker Health Reference Center of Santa Maria \\ Institution: Federal University of Santa Maria. \\ Santa Maria / RS - Brazil. \\ Mailing address: Lenita da Silva Quevedo - Rua Venâncio Aires, 1140 - Centro - Soledade / RS - Brazil - Zip-code: $99300-000$ - Telephone: (+55 54) 9602-4367 - \\ E-mail: lenitaquevedo@yahoo.com.br \\ Article received in 2011 May 28th. Article approved in 2011 July 10th.
}

\section{SUMMARY}

Introduction: Organic solvents have been increasingly studied due to its ototoxic action.

Objective: Evaluate the conditions of outer hair cells and olivocochlear system in individuals exposed to organic solvents. Method: This is a prospective study. 78 gas station attendants exposed to organic solvents had been evaluated from three gas stations from Santa Maria city, Rio Grande do Sul (RS). After applying the inclusion criteria, the sample was constituted by 24 individuals. The procedures used on the evaluation were audiological anamnesis, Transient otoacoustic emissions (TEOAES) and research for the suppressive effect of TEOAES. A group control (GC) compounded by 23 individuals was compared to individuals exposed and non-exposed individuals. The data collection has been done in the room of Speech Therapy of Workers Health Reference Center of Santa Maria. Results: The TEOAES presence was major in the left ear in both groups; the average relation of TEOAES signal/noise in both ears was greater in GE; the TEOAES suppressive effect in the right ear was higher in the individual of GE (62,5\%) and in the left ear was superior in GC (86,96\%), with statistically significant difference. The median sign/noise ratio of TEOAES, according to the frequency range, it was higher in GC in three frequencies ranges in the right ear and one in the left ear.

Conclusion: It was not found signs of alteration on the outer hair cells neither on the olivocochlear medial system in the individuals exposed to organic solvents.

Keywords: toluene, solvents, hearing.

\section{RESUMO}

Introdução: Solventes orgânicos são cada vez mais estudados em função de sua ação ototóxica.

Objetivo: Avaliar a condição das células ciliadas externas e o sistema olivococlear medial de sujeitos expostos a solventes orgânicos.

Método: Trata-se de um estudo prospectivo. Foram avaliados 78 frentistas de três postos de gasolina da cidade de Santa Maria, Rio Grande do Sul (RS) expostos a solventes orgânicos. Após a aplicação dos critérios de inclusão, a amostra ficou constituída por 24 sujeitos. Os procedimentos utilizados na avaliação foram anamnese audiológica, Emissões Otoacústicas Transientes (EOAT) e pesquisa do efeito supressor das EOAT. Um grupo controle (GC) composto por 23 sujeitos, foi utilizado para comparar sujeitos expostos e não-expostos. A coleta de dados foi realizada na sala de Fonoaudiologia do Centro de Referência em Saúde do Trabalhador de Santa Maria.

Resultados: A presença de EOAT foi maior na orelha esquerda em ambos os grupos; a média da relação sinal/ruído das EOAT de ambas as orelhas foi maior no GE; o efeito supressor das EOAT na orelha direita foi maior nos sujeitos do GE $(62,5 \%)$ e na orelha esquerda foi superior no GC $(86,96 \%)$, com diferença estatisticamente significante. A mediana da relação sinal/ruído das EOAT, segundo a faixa de frequência, foi maior no GC em três faixas de frequência na orelha direita e em uma na orelha esquerda.

Conclusão: Não foram encontrados sinais de alteração nas células ciliadas externas nem no sistema olivococlear medial nos sujeitos expostos a solventes orgânicos.

Palavras-chave: tolueno, solventes, audição. 


\section{INTRODUCTION}

In an exposition scenario combined to unhealthy agents, the individual variable of human being difficults the risks characterization and separate from the effects of each agent, like noise and chemical agents (1).

The American Conference of Governmental Industrial Hygienists (2) recommends performing periodic audiometry in subjects exposed to noise and carbon monoxide, lead, manganese, styrene, toluene or xylene. However, the literature highlights that the traditional form $\mathrm{f}$ investigation of hearing loss only by tone, cannot be enough of adequate when studies of effects to chemical exposition agents (3).

Given the solvent as toluene and styrene affects the outer hair cells (OHC), the otoacoustic emissions (OAE) are recommended to detect lesion in these cells. In fact, a great number of OAE may be lost before a hearing disorder with permanent change of threshold is detected. Until $70 \%$ de OAE in the third line of cochlear apical turn of rats can be destroyed without any significant effect of hearing (4).

Recently, there are evidences that hair cells of the organ of Corti can also be damaged by solvents. The toluene ototoxicity can result in motility disturbance of hair cells and, consequently, in sensitivity to sound. The dysmorphia caused in these cells and the prejudices in regulation of intracellular calcium level occur quickly, even in low concentrations of toluene. The OAE maight be particularly vulnerable to the ototoxics agents which disturb the intracellular calcium regulation (5).

The test of TEOAE is used to monitor the cochlear function and it is sensitive to the initial stages of changes in cochlear function, which helps in precocious diagnosis (6).

The TEOAE suppression characterize by a range reduction when is introduced a stimulus suppressor contralateral, ipsilateral or binaural $(7,8)$. The suppression of TEOAE result in activate the efferent ways which module the contraction of $\mathrm{OHC}$ being possible to affect the cochlear process responsible by TEOAE generation (7).

Thus, the present work had the objective to evaluate the conditions of external hair cells and of medial olivocochlear system in subjects exposed to organic solvents.

\section{METHOD}

The present work is a study of quantitative nature. The project of research was approved by the Ethics and
Research Committee in Human beings of Federal University of Santa Maria (UFSM) under number 23081.011007/201080 and it was executed in partnership with Worker Health Reference Center (CEREST) of Santa Maria (RS).

It was studied the cochlear condition and the medial olivocochlear system in gas station attendants exposed to organic solvents which compose gasoline.

The individuals were evaluated after reading and signing the consent term (TCLE).

The individuals of group study were gas station attendants exposed to organic solvent, being 21 of masculine gender and 03 of feminine gender, with age group varying from 20 to 40 years-old.

Among the eight gas station of Santa Maria city (RS) with greater capacity of storage and operation within 24 hours, three were chosen randomly. It was obtained a total of 78 workers.

The criteria of inclusion were: do not possess otological history, present normal hearing threshold (250 to $8000 \mathrm{~Hz}$ ) and tympanometry curve type $\mathrm{A}$, having less than 40 years-old, not having history of noise exposure, organic solvents or pesticides, do not use ototoxics medication.

After application of inclusion criteria in 78 subjects who work in 03 gas stations the sample was composed of 24 subjects, being 21 of masculine gender and three of feminine gender.

All of the subjects worked at gas station platform supply, being exposed to organic solvents vapors which compose gasoline. The exposure time varied among one to 17 years.

A control group was used in order to compare the subjects exposed and non-exposed to chemical agents. The control group was composed of subjects without history of noise and chemical products exposure, and without history of hearing changes. They were 20 men and three women, in age group between 20 and 38 years-old.

The data collection were performed in a Speech Therapy room of CEREST at Santa Maria.

The procedures used were: audiological anamnesis, inspection of external auditory canal, research of Transient otoacoustic emissions (TEOAE) and suppression of TEOAE.

The inspection of external auditory canal with clinical otoscope Klinic Welch-Allyn, aiming to verify the 
excessive presence of cerumen or any other change which would block the examination or which could change the result of them. The audiological evaluation was performed in an acoustically treated booth.

After anamnesis and the basic audiological evaluation, the included subjects in the sample were submitted to the research of TEOAE occurrence and the suppressor effect of it.

The TEOAE and the effect suppressor observation were performed by EP15 device, from brand Interacoustics. It was analyzed the TEOAE (click) in frequency ranges of $0,5-1,5 \mathrm{kHz}, 1,5-2,5 \mathrm{kHz}, 2,5-3,5$ $\mathrm{kHz}, 3,5-4,5 \mathrm{kHz}, 4,5-5,5 \mathrm{kHz}$ and the general response to the emissions. It was considered the presence of TEOAE when the general response was above of $6 \mathrm{~dB}$, with response reproducibility and sound stability superior to $70 \%$.

The research of suppressor effect of TEOAE was performed with register of TEOAE with non linear click to $75 \mathrm{~dB}$ SPL, with and without presence of contralateral white noise to $55 \mathrm{~dB}$ SPL with headset TDH 39 of audiometer AC40 from Interacoustics. The headset was positioned at the same moment that the probe, in order to this could not change the position to evaluate the suppressor effect.

The suppressor effect of TEOAE was considered present when the difference of the general response with and without contralateral noise was greater than zero. The suppression was considered absent when the difference of general response with or without contralateral noise was equal or lower than zero.

Aiming to exclude the possibility of hearing changes caused by elevated sound pressure level it was measured the level of pressure sound in participants of this study of three gas stations. The measurement was performed with a dosimeter model Q-400, adjusting to compensation scale "A" and the speed of slow response (slow). The device was placed at the worker waist and a microphone was set near to his ear, without interfering in his movements. The dosimeter was set at 08am and taken off at $04 \mathrm{pm}$, time correspondent daily working hours.

The statistical analysis was performed using the Test $\mathrm{t}$ and the Wilcoxon's Test.

\section{RESULTS}

The study group was represented by $12,5 \%$ of feminine gender and $87,5 \%$ of masculine gender. The average age was of 28,62 years.

It was not found statistically significant difference between right and left ears, from two groups, regarding the occurrence of TEOAE ( $\mathrm{GC} p=0,309$; $\mathrm{GE} \mathrm{p}=0,871$ ) and the suppressor effect of TEOAE ( $G C p=0,772$; $G E p=0,267$ ).

In the analysis of both ears together, the occurrence of TEOAE was greater in the study group, however without significant statistically difference (Table 1).

When both ears were analyzed together, it was observed that the overall average of signal/noise relation of TEOAE was greater in study group $(10,833 \mathrm{~dB})$ than the control group $(10,717 \mathrm{~dB})$. However, there was no difference statistically significant between groups (Figure 1).

The TEAOE occurrence was also analyzed by frequency range and the results will be shown bellow, according to ear.

Table I. Occurrence of TEOAE in study group and control group, in both ears.

\begin{tabular}{lccc}
\hline & GE & GC & p-value \\
\hline Presence ofTEOAE & $40(83,3 \%)$ & $38(82,6 \%)$ & 0,571 \\
Absence ofTEOAE & $8(16,7 \%)$ & $8(17,4 \%)$ & \\
\hline
\end{tabular}

Caption: TEOAE: transient otoacoustic emissions; GE: study group; GC: control group.

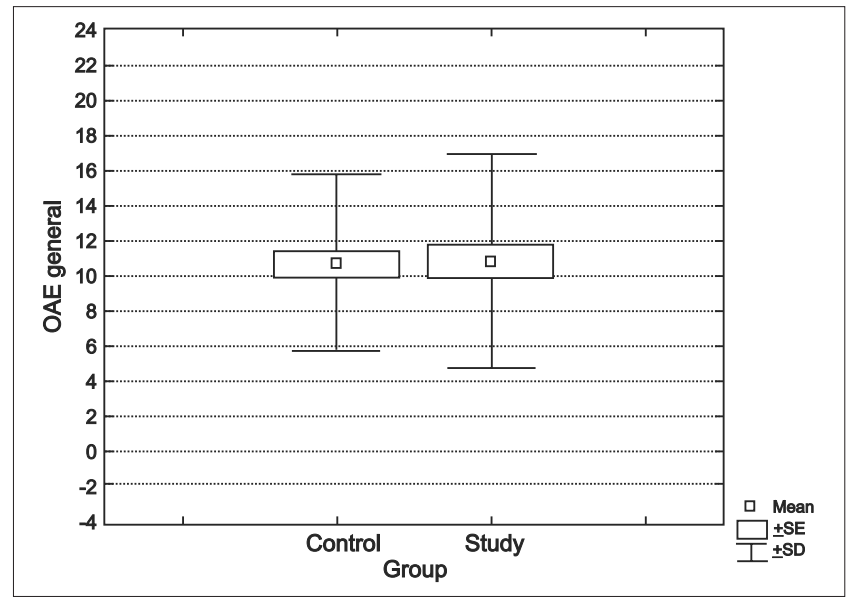

Figure 1. Average relation signal noise of TEOAE in both ears, according the group.

TEOAE: transient otoacoustic emissions; SD: standard deviation; SE: without statistical difference. 
Table 2. Occurrence of suppressor effect of TEOAE in study group and control group, in both ears.

\begin{tabular}{lccc}
\hline & GE & GC & p-valor \\
\hline Suppression presence & $28(58,3 \%)$ & $33(71,7 \%)$ & 0,126 \\
Suppressionabsence & $20(41,7 \%)$ & $13(28,3 \%)$ & \\
\hline
\end{tabular}

Caption: TEOAE: transient otoacoustic emissions; GE: study group; GC: control group.

In the right ear was observed in the control group that in two frequencies $(0,5-1,5 \mathrm{kHz}$ e $1,5-2,5 \mathrm{kHz})$ the medians were higher than those in the study group. In the other frequency bands, the medians were superior in study group. It was not observed significant statistically difference in none of the frequency ranges, in this ear. The same happened to the LE, except at frequency band of 0,5 $1,5 \mathrm{kHz}$ (Figures 2 e 3 ).

The following tables show the obtained results in the evaluation of suppressor effects of TEOAE.

In the analysis of both ears together, the presence of suppressor effects of TEOAE was greater in control group (Table 2)

The presence of suppressor effect was greater in the study group $(62,5 \%)$ in relation to the control group $(56,52 \%)$ in right ear, although there was no significant statistically difference $(p=0,5)$. In the other hand, in left ear, the suppressor effect was superior $(86,96 \%)$ and statistically significant $(\mathrm{p}=0,0236)$ in control group.

The overall average of suppressor effect, with both ears analyzed together, it was greater in control group $(9,217 \mathrm{~dB})$ in relation to the study group $(9,042 \mathrm{~dB})$. However, the difference was not considered statistically significant (Figure 4).

Despite of not being detected a statistically significant difference, the overall average signal/ noise was $(10,35 \mathrm{~dB})$ than in the control group $(10,75 \mathrm{~dB})$. But, the suppressor effect of TEOAE in right ear was greater in control group $(11,09 \mathrm{~dB})$ than in study group $(10,92 \mathrm{~dB})$. The opposite occurred in left ear, where the average relation signal/ noise observed in control group $(11,90 \mathrm{~dB})$ was greater than observed in study group $(10,92 \mathrm{~dB})$, and the suppressor effect was greater in study group $(9,75 \mathrm{~dB})$ than in control group $(9,13 \mathrm{~dB})$ (Figure 5).

After the measurement of sound pressure levels in each gas station, we verified that none of them presented sound pressure level above the tolerance threshold established by norm NR-15.

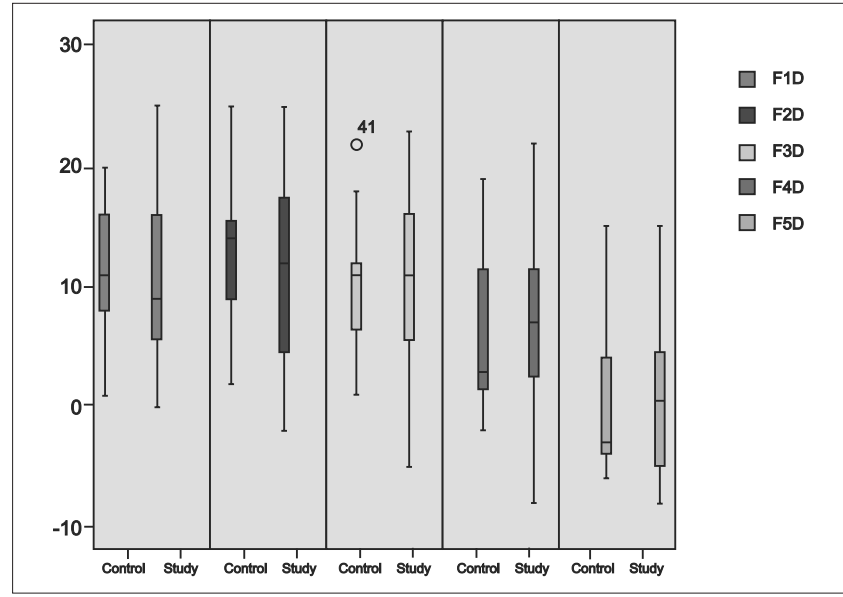

Figure 2. Median TEOAE signal to noise ratio in the right ear, according to the group and frequency range.

GE: study group; GC: control group; Hz: Hertz.

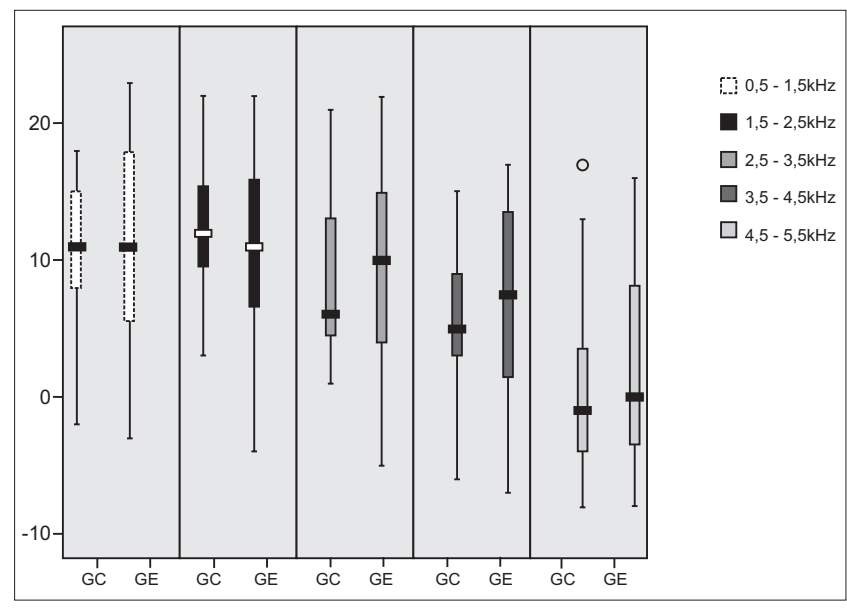

Figure 3. Median TEOAE signal to noise ratio in the left ear, according to the group and frequency range.

GE: study group; GC: control group; Hz: Hertz.

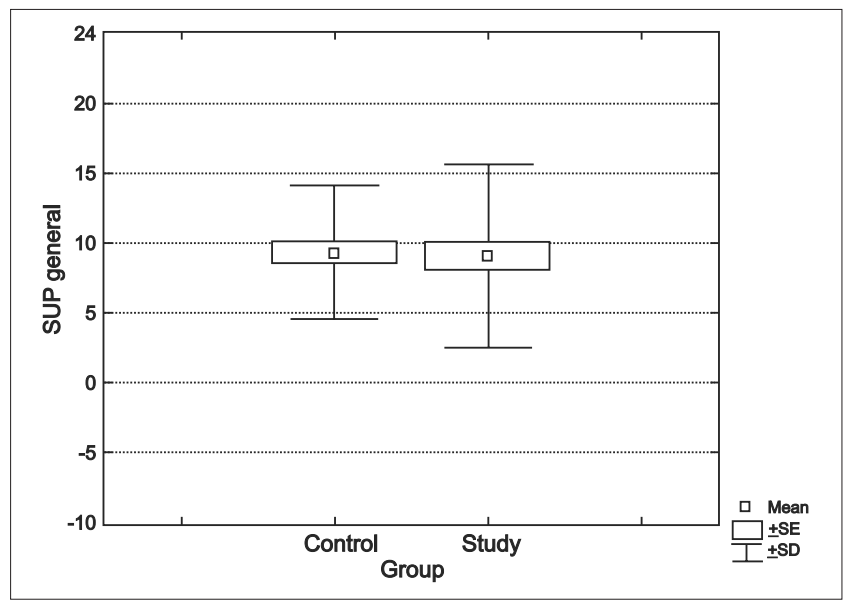

Figure 4. Overall average of suppression of TEOAE in both ears, according the group.

SUP: suppression effect; SD: pattern deviation; SE: Without statistical difference. 


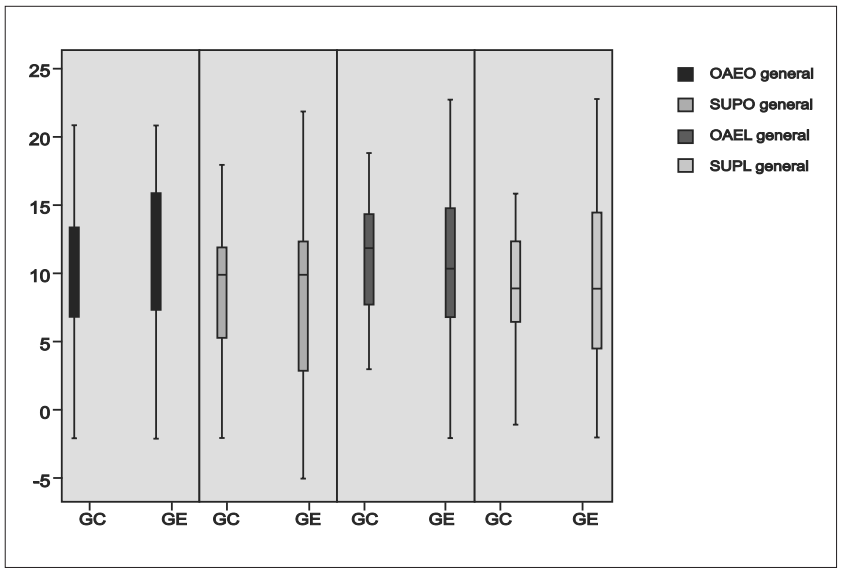

Figure 5. Mean values tof signal / noise TEOAE and of suppression in both groups and ears.

OAER: right ear otoacoustic emissions; OAEL: left ear otoacoustic emissions; SUPD: right ear suppression; SUPE: left ear suppression; GC: control group; GE: study group.

\section{DISCUSSION}

The studied group was represented by $12,5 \%$ of feminine gender and $87,5 \%$ of masculine gender and the average age was of 28,62 year.

It was not found statistically significant difference regarding the occurrence of TEOAE and the suppressor effect of TEOAE between the right and left ears, from two groups (Tables 1 and 2).

The difference of TEOAE observed in this study, was greater in the left ear, for both the control group as for the study group. This finding is not according with a study (9) which evaluated subjects exposed to solvents, and yet with other research (10) which evaluated subjects exposed to noise and organic solvents. Both of works referred that the left ear from study group there were absence of TEOAE.

It the analysis of both ears together, the occurrence of TEOAE was greater in study group $(83,3 \%$ ) (Table 1 ), as well as overall average of relation signal/ noise of TEOAE (Figure 1), despite of having no statistically significant difference between the groups. A study (11) observed a best amplitude of TEOAE between the exposed individuals than among the exposed to solvent, however it was also not found significant difference between the groups regarding on the mean amplitude of the right ear and left ear.

Analyzing the ears together TEOAE was greater in control group (Table 1). Another study (12), the absence of TEOAE was greater in group exposed to noise and toluene (64\%), followed by the group exposed only to noise (62\%), and $27 \%$ in control group.

Working with guinea pigs, in which it was analyzed the DPOAE amplitudes, showed significative reduction of amplitude of DPOAE after exposition to styrene. The exposition to toluene did not caused variation in the amplitude of DPOAE (13). In the other hand, in guinea pigs exposed to toluene (1400 ppm, 16 hours/day, during 8 days) there was reduction in amplitude of DPOAE directly proportional to exposure time (14).

The great sentivity of TEOAE was to detect the minimum cochlear changes, it was confirmed in a research (10) where subjects exposed to noise and solvents presented to greater absence in TEOAE than in DPOAE.

All of the subjects from study group presented hearing normal threshold, however it was observed absence of TEOAE in both ears (Table 1). Analyzing the TEOAE data and of tone audiometry, other researchers (10) also found that some participants who did not presented changes in audiometry, presented changes in TEOAE, both transient and distortion product. In similar study (5) the study group subjects who presented normal hearing threshold were divided in two subgroups: exposed to low and medium solvents concentrations. In the first subgroup the TEOAE were present in $49 \%$ of subjects and DPOAE $54 \%$. In group exposed to medium concentrations the occurrence of TEAOE were of $6,5 \%$ and DPOAE was of $1,6 \%$. In a third group, exposed to higher concentrations, none subject presented normal hearing threshold and the occurrence of TEOAE was of $1,6 \%$, both in TEOAE and DPOAE. Such findings showed the preventive character and monitoring of TEOAE. The use of TEOAE might be an important instrument of epidemiological surveillance in work environment, by the fact of being capable to detect precociously the cochlear changes, even before the hearing threshold present changes (12).

Even having the affected OHC by the solvent action, the cochlear change might not manifest the audiometric results. Findings of studies with guinea pigs showed by histology, the ototoxicity of toluene, where lesions in three rows of OHC were observed. The loss of most important OHC occurred in the third row and the minor losses in the first. These losses have focused on the sensitive area of the cochlea to average frequencies (10$25 \mathrm{kHz}$ ), where the damage of $\mathrm{OHC}$ reached, in average, to 90,50 and $25 \%$ of OHC in third, second and first row, respectively $(15,16,17)$.

The presence of suppressor effect was greater in study group $(62,5 \%)$ in relation to the control group 
$(56,52 \%)$ in right ear, however there was no statistically significant difference. Other findings showed the suppressor effect in the right ear in $73,97 \%$ of individual exposed to solvents and $75,5 \%$ of the individuals non exposed (11).

In other hand, in the left ear, the presence of suppressor effect was superior and statistically significant in control group $(86,96 \%)$ in relation to study group $(54,17 \%)$. The findings of this study are in agreement with other studies (11), due to the suppressor effect of TEOAE was observed in the left ear in $68,65 \%$ of the subjects ( $n=$ 46) exposed to solvents. In the group non exposed, there was presence of suppressor effect in $75,75 \%(n=75)$ of individuals. However, the author findings were not statistically significant.

In the analysis of both ears together, observed the presence of suppressor effect of TEOAE was greater in control group (Table 2). In the same way, the overall average of suppressor effect, analyzed with both ears together, it was great in control group $(9,217 \mathrm{~dB}$ ) (Figure 2). However, such difference was not statistically significant. In other research (12), although there was the noise accompanying the solvent, it was observed similar findings to the present study, as the absence of suppressor effect was greater in the group exposed simultaneously to noise and toluene $(48,9 \%)$ than in exposed groups to noise and control group. The absence of suppressor effect shows retrocochlear compromise. Thus, these results suggest a neurotoxic action of toluene over hearing, affecting the retrocochlear portion of hearing ways, differently of lesion caused by noise. The author highlights that the register of TEOAE and the analysis of suppressor effect can be used in precocious detection of hearing lesions of cochlear and retrocochlear origin (12).

The greater occurrence of suppression observe in non exposed group to solvents suggest that the medial olivocochlear tract can be affected in individuals exposed to organic solvents $(11,12)$.

It was analyzed the overall average of relation signal noise in each ear, as well as the suppressor effect, according to the group (Figure 5). Despite of having not being detected the statistically significant difference, the overall average of relation signal noise of TEOAE in right ear was greater in group study $(10,35 \mathrm{~dB})$. In left ear the average relation signal noise of TEOAE was greater in control group $(11,90 \mathrm{~dB})$. The suppressor effect in right ear was greater in control group $(11,09 \mathrm{~dB})$ than in study group $(10,92 \mathrm{~dB})$ and in the left ear it was greater in study group $(9,75 \mathrm{~dB})$ than control group $(9,13 \mathrm{~dB})$.

In control group the two range of frequencies $(0,5-1,5 \mathrm{kHz}$ and $1,5-2,5 \mathrm{kHz})$, in right ear, presented higher median of the signal / noise, thus the difference was not statistically significant (Figure 2). The similar findings were observed in other study, in right ear, where the significative differences were found in three frequencies band (1 kHz, $2 \mathrm{kHz}$ e $3 \mathrm{kHz})$ (11).

In left ear, the present study showed higher median in the control group only in a frequency range (1,5 $2,5 \mathrm{kHz}$ ) (Figure 3). Similar findings were reported (11), where significative differences between the groups were found only in band of $2 \mathrm{kHz}$, in same ear.

The mechanism of lesion of Corti organ has been explained in different ways. It is probable that the lesion of Corti organ by solvent be different from caused by antibiotics. A study (15) about route of intoxication occurred in guinea pigs, showed that toluene did not reached Corti organ through the fluids of inner ear, because the solvents were rarely found. The authors suggest two likely routes of intoxication in hearing disturb induced by aromatic solvents. In the first, the solvents would be spread from the eighth nerve to hair cells, as the concentration of solvents found in the nerve was greater than in blood. However, it is difficult to explain the pathological pattern of damage of Corti organ by solvents. The inner hair cells would be damaged as much or more than the OHC according to this model (16), which becomes contradictory once the $\mathrm{OHC}$ are more sensitive to toluene than the inner hair cells (15).

In the second route of intoxication the solvents would be transported by blood which comes through stria vascularis or spiral prominence, would spread over the groove for the external lipid-rich membranes and would reach the Hensen cells, rich in lipids. The Hensen cells are not in connection to the Deiter cells, which are located under OHC. The external groove might be the preferential route by which the solvents reach the Corti organ. In sum, the damages induced by solvent are not caused by fluid contamination, but by intoxication of tissue that involve the external groove, instead of the auditory nerve (16).

The sound pressure levels observed in gas stations were not harmful to hearing (Table 3). Thus, the findings of this study might be attributed to the possible ototoxic action of solvents.

Different industrial scenario, the gas station is an open occupational environment, in which the solvents might be less concentrated in the air. Thus, the inhalation and absorption of agents would be reduced. Consequently, the action over auditory system also might be lower. This could explain the low rate of cochlear changes and of olivocolear medial system found in study group of present research. 
Table 3. Sound pressure level measured in three gas station of study.

\begin{tabular}{lc}
\hline Gas Station & Level of sound pressure \\
\hline Gas Station 1 & $76,0 \mathrm{~dB}$ \\
Gas Station2 & $70,6 \mathrm{~dB}$ \\
Gas Station3 & $71,5 \mathrm{~dB}$
\end{tabular}

Caption: dB: decibel

\section{CONCLUSION}

In conditions in which the subjects of this study were exposed, it was not found the change in external hair cells in olivocolear medial system.

\section{BIBLIOGRAPHIC REFERENCES}

1. Johnson AC, Morata TC. Occupational exposure to chemicals and hearing impairment. The Nordic Expert Group for Criteria Documentation of Health Risks from Chemicals, 2010, 44:1-177.

2. ACGIH. TLVs and BEIs. Based on the documentation of the threshold limit values for chemical substances and physical agents and biological exposure indices. Cincinnati, Ohio: American Conference of Governmental Industrial Hygienists, 2009.

3. Morata T, Lemasters GK. Epidemiologic considerations in the evaluation of occupational hearing loss. Occupational Medicine: State of the Art Reviews. 1995, 10:641-56.

4. Pouyatos B, Campo P, Lataye R. Use of DPOAEs for assessing hearing loss caused by styrene in the rat. Hear Res. 2002, 165:156-164.

5. SuBkowski WJ, Kowalska S, Matyja W, Guzek W, WesoBowski W, Szymczak W, et al . Effects of occupational exposure to a mixture of solvents on the inner ear: A field study. Int J Occup Med Environ Health. 2002, 15:247-56.

6. Aquino AMCM, Massaro CAM, TiradentesJB, Garzón JCV, Oliveira JAA. Emissões otoacústicas no diagnóstico precoce de lesão coclear na doença de Meniére. Rev Bras Otorrinolaringol. 2002, 68:761-6.
7. Collet L, Kemp DT, Veuillet E, Duclaux R, Moulin A, Morgon A. Effect of contralateral audititory stimuli on active cochlear micro-mechanical properties in human subjects. Hear Res. 1990; 43:251-62.

8. Hood LJ, Berlin CI, Hurley A, Cecola P, Bell B. Contralateral suppression of transient-evoked otoacustic emissions in humans: intensity effects. Hear Res. 1996, 101:113-8.

9. Gopal KV. Audiological findings in individuals exposed to organic solvents: Case studies. Noise Health. 2008, 10:7482.

10. Cardoso PCM, Viana KS, Oliveira JS, Castro IM. Audição em trabalhadores de manutenção de aeronaves. Revista do Centro de Ensino Superior Unificado de Brasília. 2004, 1:215:232.

11. Fuente A. Auditory Damage Associated with Solvent Exposure: Evidence from a Cross-Sectional Study. Hong Kong, 2008, p.376 (Tese de Doutorado - University of Hong Kong).

12. Bernardi APA. Trabalhadores expostos simultaneamente a ruído e tolueno: estudo das emissões otoacústicas evocadas transitórias e efeito de supressão. Dissertação de Mestrado, São Paulo, 2000, p.141 (Tese de Mestrado - Faculdade de Saúde Pública, Universidade de São Paulo).

13. Lataye R, Campo P, Pouyatos B, Cossec B, Blache're V, Morel G. Solvents ototoxicity in the rat and guinea pig. Neurotoxicology and Teratology, 2003, 25:39-50.

14. Johnson AC, Canlon B. Toluene exposure affects the functional activity of the outer hair cells. Hear Res. 1994, 72:189-96.

15. Campo P, Lataye R, Cossec B, Placid V. Toluene-induced hearing loss: a mid-frequency location of the cochlearlesions. Neurotoxicology and Teratol. 1997, 9:129-140.

16. Campo P, Loquet G, Blachère V, Roure $M$. Toluene and styrene intoxication route in the rat cochlea. Neurotoxicology and Teratol. 1999, 21:427-434.

17. Gagnaire F, Langlais C. Relative ototoxicity of 21 aromatic solvents. Arch Toxicol. 2005, 79:346-354. 